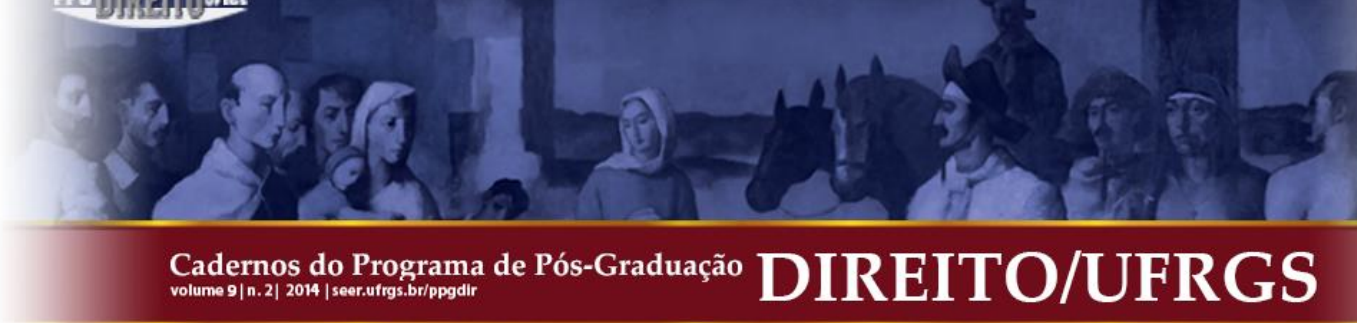

\title{
ECONOMIA POLÍTICA CONSTITUCIONAL: PROGRAMA DE PESQUISA JAMES BUCHANAN E AS TECNOLOGIAS CIVIS
}

\author{
CONSTITUTIONAL POLITICAL ECONOMY: JAMES BUCHANAN RESEARCH PROGRAM \\ AND THE CIVIL LAW TECHNOLOGIES
}

\author{
Andrei Cesário de Lima Albuquerque* \\ Heraldo Elias Montarroyos ${ }^{* *}$
}

\begin{abstract}
RESUMO: O objetivo desse artigo é identificar os custos e os benefícios projetados pelas tecnologias jurídicas do Código Civil, aplicando o programa de pesquisa da Economia Política Constitucional do economista James Buchanan (1975) que funciona como instrumento heurístico decisivo nesse estudo para compreender a dinâmica institucional da Lei a partir da lógica utilitaristamaximizadora do homem racional. Esse programa de pesquisa apresenta uma ontologia, metodologia, axiologia, teoria, práxis e um contexto social das ideias. Com essas categorias, é realizada a releitura instrumental do Código Civil que aponta como resultado a existência de quatro tecnologias contratuais (negociação, centralização, descentralização e coalizão) apresentando seus respectivos custos e benefícios institucionais. Também, procurando maximizar o programa de pesquisa buchaniano, acrescentamos o programa de pesquisa da ação coletiva do economista Mancur Olson, igualmente estruturado em categorias diversas, com o intuito de visualizar a interferência do indivíduo free rider no desempenho das tecnologias jurídicas. Como contribuição, essa pesquisa metodológica mostra que existe uma microeconomia política no Código Civil brasileiro.
\end{abstract}

PALAVRAS-CHAVE: Racionalidade Econômica; Tecnologia jurídica; Bem público; James Buchanan.

\begin{abstract}
This paper seeks to identify the costs and benefits designed by the legal technologies of the Civil Code, applying the research program of Constitutional Political Economy as defined by James Buchanan (1975) which is a fundamental heuristic tool in this study to understand the institutional dynamics of Law from the rational man's utilitarian-maximizing logic. This research program presents an ontology, a methodology, an axiology, a theory, a praxis, and a social context of ideas. With these categories, it is performed the instrumental reinterpretation of the Civil Code which points as a result to the existence of four contractual technologies (trading, centralization, decentralization, and coalition) and their respective costs and institutional benefits. Also, in order to maximize the Buchanan-esque research program, it was introduced the research program of the collective action as defined by Mancur Olson, equally structured into several categories, in order to see the interference of the free rider individual in legal technologies' performance. As a contribution, this article shows that there is a political microeconomics in the Brazilian Civil Code.
\end{abstract}

KEYWORDS: Economic Rationality; Legal Technology; Public Good; James Buchanan.

SUMÁRIO: Introdução. 1. Programa de pesquisa James Buchanan. 2. Programa de pesquisa complementar. 3. Tecnologia da negociação jurídica. 4. Tecnologia Da Centralização Civil. 5. Tecnologia da descentralização civil. 6. Tecnologia da coalizão. 7. Discussão. Considerações finais. Referências.

\section{INTRODUÇÃO}

O objetivo desse estudo é aplicar no Código Civil brasileiro o programa de pesquisa da Economia Política Constitucional, do economista James Buchanan, auxiliado pelo programa da ação coletiva do autor Mancur Olson, visando conhecer especialmente os custos e benefícios institucionais projetados pelos contratos civis decorrentes da interação da

\footnotetext{
* Graduando em Direito na Universidade Federal do Sul e Sudeste do Pará (UNIFESSPA).

** Doutorado em Filosofia pela Universidade de São Paulo. Mestrado em Ciência Política pelo Instituto Universitário de Pesquisas do Rio de Janeiro. Professor da Universidade Federal do Pará.
} 


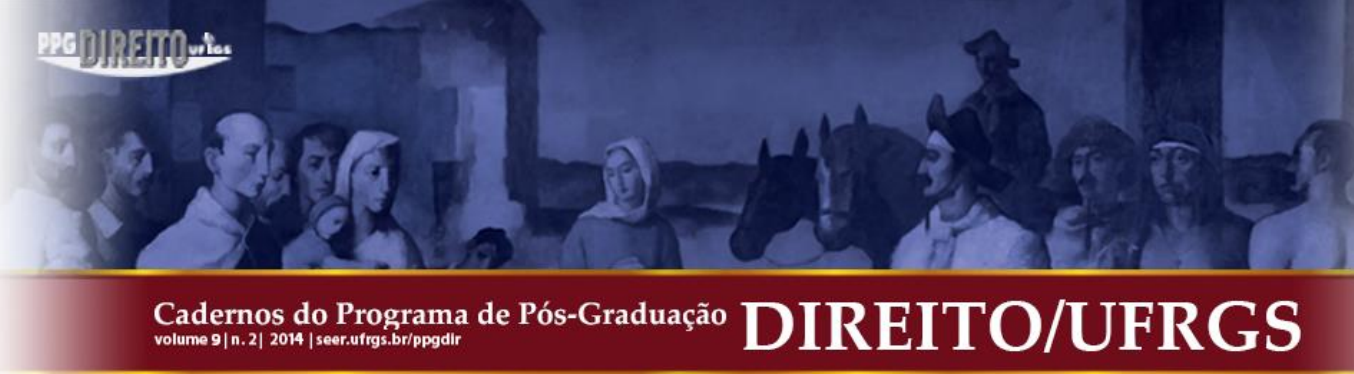

para o homem econômico efetivar seus projetos pessoais nos limites da ordem pública e dos bons costumes. Nesse quadro teórico, portanto, a informação jurídica disponibilizada gratuitamente pelas normas públicas possibilita ao homem racional a oportunidade de agir dentro da legalidade ajustando ou adaptando a tecnologia civil que poderá otimizar os seus interesses nos limites da racionalidade social.

\section{PROGRAMA DE PESQUISA JAMES BUCHANAN}

Empiricamente, o homem racional se comporta desenvolvendo o princípio utilitaristamaximizador. Ou seja, ele sempre vai realizar as suas escolhas virtualmente numa escala de transitividade (colocando as opções em termos de primeiro, segundo e terceiro lugar) e assim espera escolher o melhor produto e obter o lucro internalizando nesse caso o mínimo de custos sociais e econômicos. Dentro desse contexto, é essencial admitir-se o fato de que os indivíduos se comportam de maneira racional procurando satisfazer suas demandas institucionais quando usam regras públicas, o que justifica a aplicação da analogia econômica como recurso metodológico bem sucedido nesse caso a fim de sistematizar e compreender a dinâmica dos fatos jurídicos pelo prisma da racionalidade (MONTARROYOS, 2009).

Visando frear o ímpeto egoísta e privatizador do homem racional são necessárias regras, princípios e critérios que se traduzem na prática em custos institucionais da legalidade. Os custos material e psicológico dessa legalidade (também conhecido esse último como custo de oportunidade) se impõem especificamente ao homem racional de modo a influenciar as suas escolhas, limitando os seus desejos até então ilimitados no mundo natural.

Devem ser considerados especialmente os custos na formulação da escala de transitividade, principalmente os custos de oportunidade que se referem às alternativas sacrificadas ou trocadas quando se escolhe um produto ou serviço que extrapola o poder aquisitivo da pessoa em determinado momento. Todavia, ao lado dos custos, comportar-se dentro da Lei também traz benefícios, que teoricamente são estímulos positivos, como segurança, estabilidade das relações, previdência em caso de sinistro, etc.. Todos esses benefícios são prometidos contratualmente ao homem racional no instante da escolha pública, ao se ingressar ou não no domínio de determinada Lei, ao lado dos custos materiais e subjetivos das escolhas. 


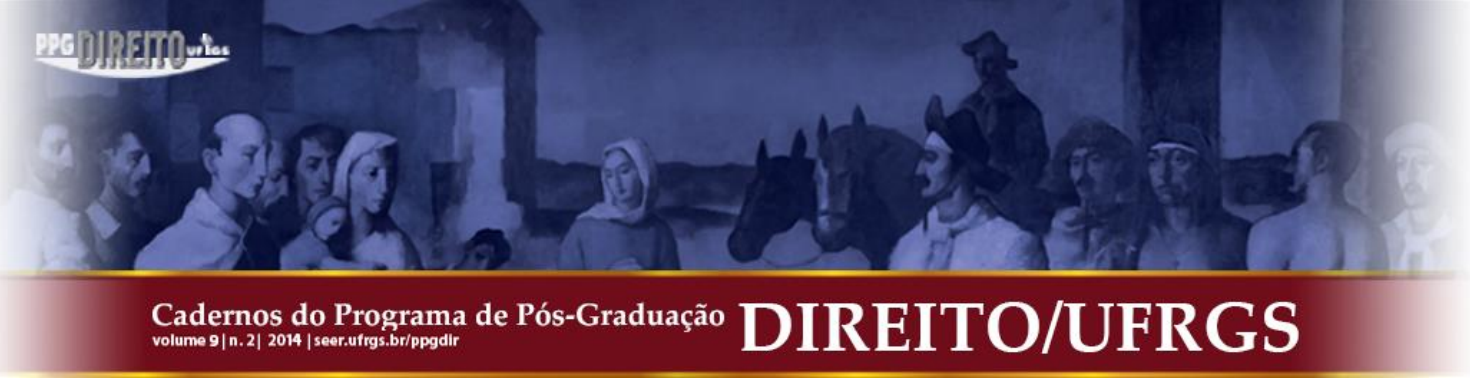

Empiricamente, é importante reconhecer o fato de que existem alternativas civis teoricamente extremas e que cada uma delas possui uma estrutura objetiva de custos e benefícios institucionais; porém, a escolha desse ou daquele modelo de ação contratual dependerá do contexto influenciado pelos riscos, incertezas e instabilidades do ambiente (MONTARROYOS, 2009). Neste contexto programático, ficar sozinho é uma opção inicial, porém, quando o indivíduo avalia os custos de oportunidade entre a liberdade natural e a liberdade vigiada ou civil, os benefícios disponibilizados pela segunda alternativa deverão satisfazer necessariamente aos interesses do homem racional, garantindo-lhe, por exemplo, o poder de pesquisar preços, de negociar, e de realizar trocas positivas com seus pares aceitando a fiscalização coletiva do grupo ou pública do Estado.

$\mathrm{Na}$ verdade, o estado ideal para o homem econômico seria a anarquia, mas ele reconhece estrategicamente que para fazer as suas transações é necessário o mínimo de previsibilidade e de estabilidade no mercado. Existe, portanto, um paradoxo no homem racional, o paradoxo do governado, segundo o economista James Buchanan (1975). Ou seja, ao mesmo tempo em que o indivíduo racional quer ser livre, admite ser limitado pelo Estado.

A fundação de grupos como firmas e condomínios acarreta igualmente custos institucionais que serão maiores ou menores a depender das regras instituídas. Por exemplo, podem ser fixadas regras de maioria ou regras de unanimidade. Nas regras de maioria, a decisão é alcançada quando a maior parte do grupo se posiciona em um sentido consensual notoriamente quantitativo. Existem, nesse modelo de regras, os custos de transação que serão maiores ou menores dependendo do tamanho do grupo e de sua composição social. Por outro lado, com as regras de maioria corre-se o risco de um mesmo segmento majoritário ter perpetuada ad eternum a sua vontade quando a minoria se mantiver desarticulada ou dominada pelo sistema. As regras de unanimidade, por seu turno, garantem que a opinião de todos os participantes será ouvida integralmente, entretanto, os custos de transação podem se tornar altíssimos em grupos maiores, nesse caso, gastando-se mais tempo e energia para que se chegue a um entendimento unânime, principalmente em grupos com grande número de pessoas de diferentes culturas ou perfis sociais.

Para minimizar custos de transação social ou de barganhas, o homem racional pode então concentrar o poder político-administrativo nas mãos de alguns líderes, considerando que não existiriam custos de transação relevantes nessa escolha extrema, porém, é importante 


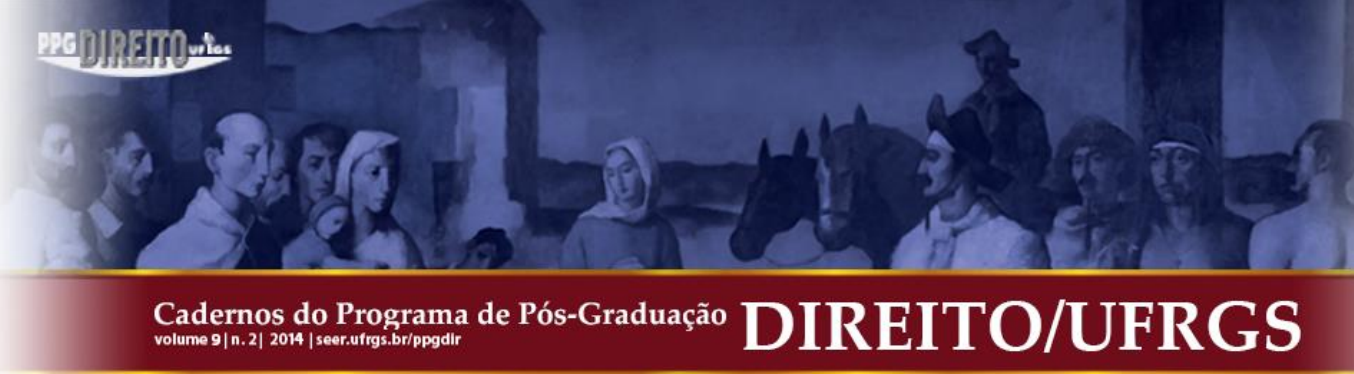

paralelos, influenciando assim o conteúdo da escala transitiva onde são feitas as escolhas individuais; entretanto, na teoria da racionalidade buchaniana o homem econômico não se confunde com o "ratinho branco de laboratório", visto que seu comportamento será sempre operante ou estratégico conforme sugere a teoria psicológica de Skinner (1977); consequentemente, devemos admitir a presença de três sujeitos atuando simultaneamente no mundo social: primeiro, o ambiente com seu poder condicionante e racionalidade pública; segundo, o homem racional com seu individualismo possessivo e racionalidade privada; e finalmente, o analista político com sua racionalidade científica dotada de classificações, diagnósticos e previsões que demonstram metodologicamente a existência de uma lógica utilitarista nas respostas individuais em relação ao ambiente social, variando nesse caso entre a total submissão ao sistema jurídico até à completa rejeição ou indiferença dos parâmetros oficiais da vida pública. Em todas essas respostas (obediência perfeita à desobediência completa) predomina o instrumentalismo, onde a eventual obediência à Lei é um meio para se obter vantagens institucionais diversas, e não um fim em si mesmo.

e) Do ponto de vista prático, existem modelos e tentativas de solução de problemas. Para cooperar, por exemplo, o homem racional poderá empregar regras de maioria ou de unanimidade. Para resolver conflitos, por outro lado, poderá escolher o modelo da anarquia hobbesiana e lockiana, ou o modelo extremo do Leviatã repressor-policial, ou então o meiotermo, que segundo James Buchanan (1975) seria uma anarquia ordenada positivada, nesse caso, conforme sugeriu oportunamente Montarroyos (2010), seria representada pela Lei de arbitragem que funciona como instrumento apaziguador e democrático dos conflitos com pouca ou nenhuma intervenção do Poder Judiciário.

f) Do ponto de vista contextual, por último, existem incentivos positivos e negativos que afetam o consumo e o desempenho das tecnologias contratuais. Entre os incentivos positivos transparece a expectativa de se obter benefícios institucionais. Entre os negativos estão a incerteza, a desordem política, o autoritarismo estatal, entre outras externalidades negativas.

\section{PROGRAMA DE PESQUISA COMPLEMENTAR}




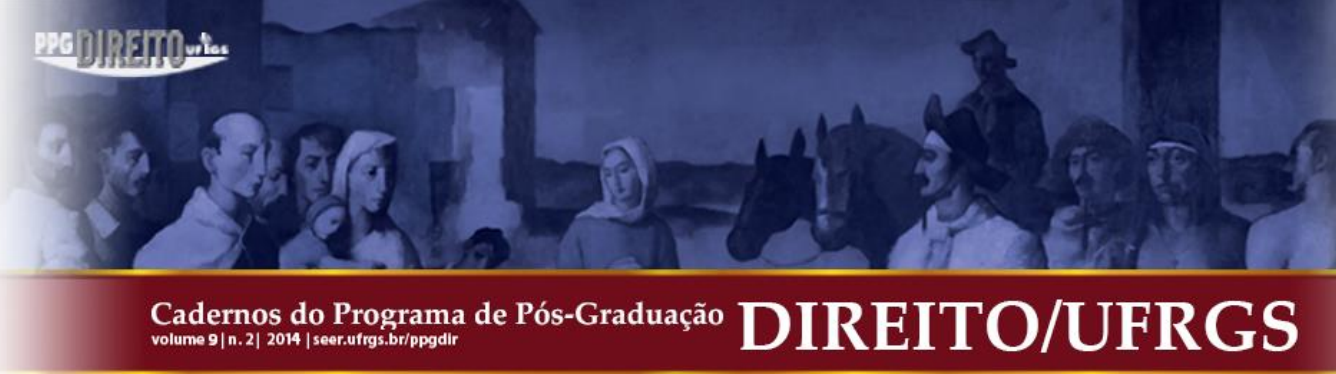

Esse programa de pesquisa serve nesse estudo para descrever o entrosamento da racionalidade privada com a racionalidade do grupo mediada pelo líder e problematizada pelo indivíduo oportunista dentro do condomínio e de outras possíveis organizações de interesses.

No modelo proposto por Mancur Olson (1999), no livro "A lógica da ação coletiva", os incentivos paralelos ou seletivos são usados nesse contexto em dois modos: positivos e negativos, sendo distribuídos pelo líder com a finalidade de fazer com que alguns membros do grupo resgatem seu interesse prático pelas assembleias e despertem o seu espírito coletivo.

Os incentivos positivos incluem mecanismos de atração coletiva em forma de condecorações, correspondências, convites especiais, menção honrosa, publicações elogiosas e outras formas de bens coletivos personalizados com a intenção de capturar ou despertar o sentimento coletivo do membro do grupo que anda meio adormecido ou desmotivado. Os incentivos negativos, por outro lado, podem considerar piquetes nas fábricas, taxações compulsórias, difamações públicas e toda sorte de constrangimentos institucionais que visem atingir e despertar a consciência coletiva do indivíduo.

Neste modelo, os grupos são considerados como organização de interesses individuais. Se a organização apresentar um grande número de pessoas, corre-se no entanto, o risco de alguns membros terem a sensação de que sua participação efetiva não causará grande influência para a realização dos objetivos gerais da coletividade.

Nos grupos grandes acontece a redução intrínseca da taxa de sacrifício individual, onde o membro será tentado a não contribuir com a expectativa de que sua ausência será preenchida de qualquer modo pelo esforço dos outros, o que muitas vezes acaba ocorrendo de fato, mas gera incertezas e crise de legitimidade nas decisões coletivas.

Por outro lado, os grupos menores têm uma relativa vantagem institucional com relação aos grandes, pois suas técnicas e métodos decisórios são mais eficientes devido à relação direta, ou cara a cara, entre seus associados. Aqui, cada membro sentirá o peso de sua importância para a manutenção do grupo e isso, por si só, já seria um enorme incentivo, além da visibilidade individual que é expressiva nesse contexto minoritário.

Seja nos grupos pequenos ou nos grandes, para Olson, portanto, a figura do líder é fundamental, pois ele será responsável pela aplicação dos incentivos mais adequados ao desenvolvimento do grupo como um todo.

O líder deve possuir expressiva habilidade para perceber quais estratégias serão mais eficientes para cumprir os objetivos do grupo. Entretanto, enfrenta riscos de decisão, pois 


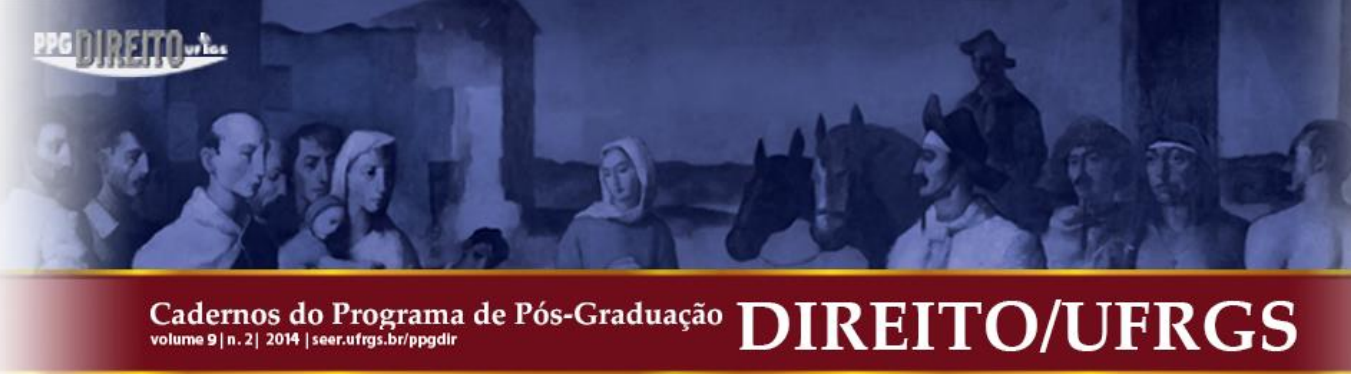

internas muito mais graves que os grandes grupos formados por pessoas com o mesmo perfil social.

d) Do ponto de vista teórico, Olson acredita no esquema comportamentalista em termos de estímulo-resposta. Grandes grupos estimulam naturalmente o desinteresse e o oportunismo, fazendo com que certas pessoas se escondam por trás da multidão. Nesse sentido, o líder deve ser estratégico e ofertar incentivos paralelos que possam atrair a participação do homem econômico. Nesse aspecto, Olson introduz mais uma novidade na psicologia do homem econômico, ou seja, além de ser calculista, sensível, ético, especulativo, etc., é socialmente "irracional" e retorna à racionalidade social apenas e tão somente se ganhar algo especial a mais que os outros no grupo, ou seja, os incentivos paralelos.

e) Do ponto de vista prático, existe uma tecnologia democrática sendo amplamente usada pelo líder empreendedor, o lobby, que funciona a partir da persuasão e sedução sobre determinados membros do grupo.

f) Do ponto de vista contextual, a questão imediata é como produzir bem público ou coletivo com tantos interesses, preferências e convicções díspares? A resposta é participar de organizações de interesses que disputam com intensidade os favorecimentos públicos do governo dentro de um modelo darwiniano de luta pela sobrevivência.

\section{TECNOLOGIA DA NEGOCIAÇÃO JURÍDICA}

No Brasil, a celebração de um negócio jurídico envolve a observância de inúmeras cautelas, muitas vezes incompreensíveis para o "usuário-padrão", visto que o cidadão comum não recebe uma educação de base para entender minimamente a lógica da Lei.

Para celebrar um negócio jurídico o usuário deve ser uma pessoa capaz, ou seja, ser maior de idade e estar em pleno uso e gozo de suas faculdades mentais. Além disso, o objeto do negócio jurídico deve ser lícito, possível, determinado ou determinável em Lei, conforme estabelece o Código Civil (art.104 em diante). 


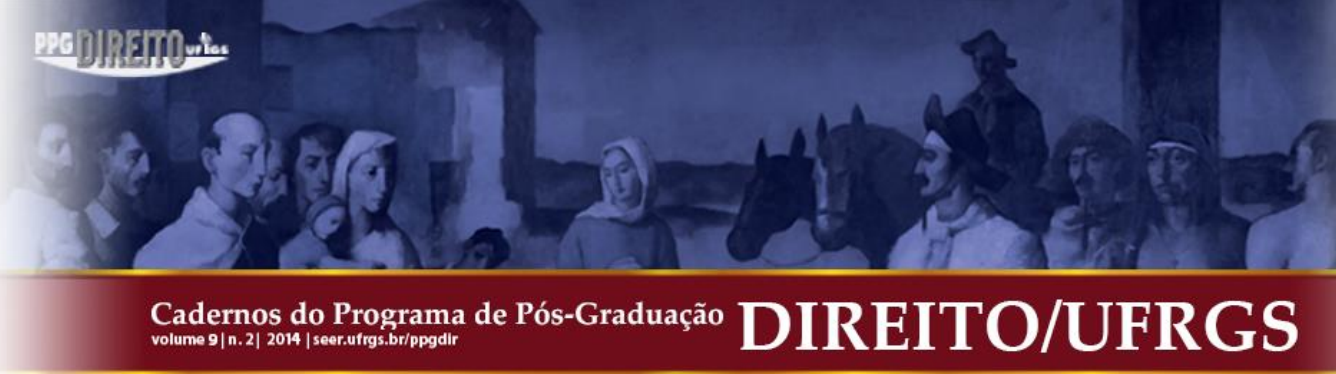

O negócio jurídico inclui também alguns princípios basilares. As partes que o celebram devem estar informadas ou direcionadas pela boa-fé; e o instrumento contratual deverá prezar pelo equilíbrio da relação entre as partes de modo que o negócio não fique oneroso demais, indevidamente. Nos termos do artigo 113 do Código Civil, por exemplo: “os negócios jurídicos devem ser interpretados conforme a boa-fé e os usos do lugar de sua celebração."

Sendo estruturas pensantes, os princípios da boa-fé e do equilíbrio devem ser observados em todas as etapas da negociação jurídica. Os princípios servem, por exemplo, para estabelecer uma relação mutuamente positiva, onde as partes ganharão na exata proporção de seus interesses que estão sendo pactuados virtuosamente nesse momento. É a racionalidade pública produzindo, nesse caso, um ambiente estratégico informacional em benefício do direito privado!

O Código Civil estabelece ainda alguns critérios para o usuário avaliar se o negócio jurídico será ou não reconhecido como válido. A Lei não aceita, por exemplo, um negócio jurídico em que haja dolo, coação, fraude contra credores, erro, etc.

Nesse momento, o Estado informa ao usuário por meio dos critérios oficiais que o poder público não vai anuir ou ordenar o cumprimento/execução de um instrumento eivado de vícios. Em verdade, diante de algum desses defeitos, o Juiz poderá efetivamente declarar nulo o negócio tendo em vista que os efeitos contratuais causariam enormes custos negativos ao homem racional.

Conclusivamente, a fiscalização e a intervenção do Estado vêm no sentido de garantir que o mínimo ético seja observado e o bem público efetivamente surja, reprimindo as surpresas egoístas ao mesmo que tempo que humaniza a conduta do cidadão com a utilização racional e efetiva de suas leis oficiais.

Pelo Código civil a tecnologia da negociação poderá se configurar na prática por meio do contrato de locação, empreitada, compra e venda, doação ou prestação de serviços. É fundamental considerar no uso de todas essas tecnologias que o usuário será um agente racional preenchendo determinados prerrequisitos, por exemplo, buscando um meio eficiente para produzir e consumir determinados bens instrumentais como ordem, previsibilidade, informação e segurança pública ou jurídica. Desse modo, os contratantes reconhecem estrategicamente a necessidade de autolimitar seus egoísmos no sentido de produzir um espaço coletivo de trocas e de comercializações. 


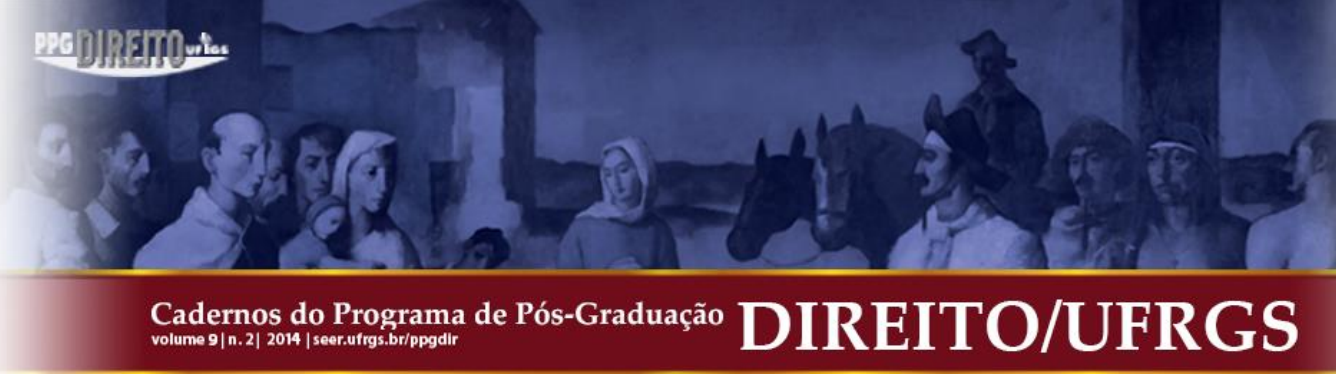

Ao celebrar um contrato escrito, portanto, os indivíduos trocam o modelo da anarquia moral lícita baseada na informalidade e entram racionalmente no império da lei positiva. Essa troca gera automaticamente custos de oportunidade, sobretudo relacionados com a supressão do poder unilateral de decisão e com a redução da autonomia individualista. Simultaneamente, as partes devem ganhar autonomia coletiva nesse processo para, por exemplo, inventar formalmente contratos atípicos, observando os bons costumes e a ordem pública.

Nesse quadro, os custos de oportunidade serão positivos na medida em que forem compensados por uma série de benefícios públicos, dentre eles a objetividade e previsibilidade do processo interativo dos contratantes. Entretanto, o aspecto nodal para a racionalidade jurídica dos contratantes será sempre evitar o estado de natureza hobbesiano, estado de guerra de todos contra todos, onde se destacam a animalidade e o individualismo possessivo. Nesse caso, felizmente, os indivíduos encontram à sua disposição informações públicas e gratuitas no Código Civil que estipula o caminho oficial que nos afasta da anarquia imoral, desordenada e ilícita.

No contrato de compra e venda, por exemplo, a Lei deixa claro o lugar da fronteira que separa o estado de natureza hobessiano do estado civil. Nesse sentido, se o contrato tiver cláusulas ambíguas e contraditórias receberá uma interpretação mais favorável ao aderente. Também se a negociação foi realizada a partir de protótipos, modelos e amostras, garante-se por Lei que o vendedor vai entregar o produto ao cliente com as mesmas qualidades amostradas (art. 488). O contrato também será nulo se apenas uma das partes definiu o preço do produto.

No contrato de doação, encontramos essa mesma preocupação de separar o estado de natureza hobbesiano do estado civil. Considera-se, por exemplo, que a doação pode ser revogada por ingratidão do donatário, por inexecução do encargo, ou quando o donatário atentar contra a vida do doador ou cometer crime ou ofensa física, se injuriar gravemente ou caluniar contra o doador ou se recusar a fornecer ao doador alimentos que este necessitava e tinha meios de atendê-lo (art. 555-57).

No contrato de empreitada, por sua vez, a obra pode ser suspensa se as modificações exigidas pelo dono da obra por seu vulto e natureza forem desproporcionais ao projeto aprovado, ainda que o dono se disponha a arcar com o acréscimo do preço (ver art. 248). 


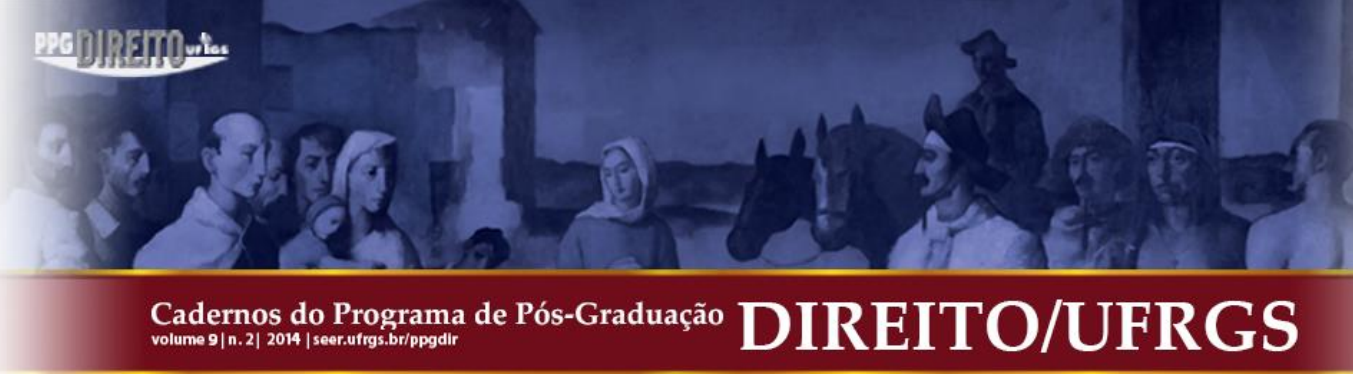

Basicamente, a tecnologia da negociação jurídica implica a seguinte economia institucional:

a) oferece custos e benefícios objetivados em Lei, onde o jogo civil determina como ponto de partida que os contratantes abdiquem da anarquia moral e prefiram o modelo da legalidade.

b) no desenvolvimento dessa troca, surgem custos de oportunidade ou psicológicos relacionados com a diminuição do poder individualista e com a restrição do egoísmo, em compensação, a seguir, os contratantes ganham bens civis como ordem, previsibilidade, informação e segurança ou menor incerteza jurídica e social dos contratos.

\section{TECNOLOGIA DA CENTRALIZAÇÃO CIVIL}

Possuindo informações públicas para realizar transações e celebrar negócios, o homem racional pode avaliar custos e benefícios dentro da legalidade. Sendo assim, ele será capaz de sacrificar a sua liberdade individualista e suprimir, ou mesmo abandonar, o poder unilateral de julgar as coisas, guiado apenas pelo seu interesse egoísta.

Talvez pelo medo do retorno ao estado de natureza hobbesiano, onde não seria possível se garantir uma racionalidade social voltada para o bem público, o indivíduo racional transfere o poder absoluto para um centro produtor de tecnologias jurídicas para resolver conflitos, objetivamente, o Leviatã.

Entretanto, aqui, a centralização civil é fruto de uma escolha racional onde o indivíduo avalia custos e benefícios entre ficar fora da Lei (estado de natureza) ou dentro da Lei (estado civil). No final, entretanto, a sua decisão vai depender do contexto, e nesse caso, idealmente, o Estado promete garantir a ordem.

Mas, paradoxalmente, quando o Estado se transforma no maior produtor de males públicos, dentre eles, desordem, impunidade, injustiça e burocratismo, pode ser um bom negócio para o indivíduo racional praticar a criminalidade. De qualquer modo, haverá sempre o risco de eventualmente ser reprimida a criminalidade - de surpresa - pelo Estado em algumas operações especiais de fiscalização. 


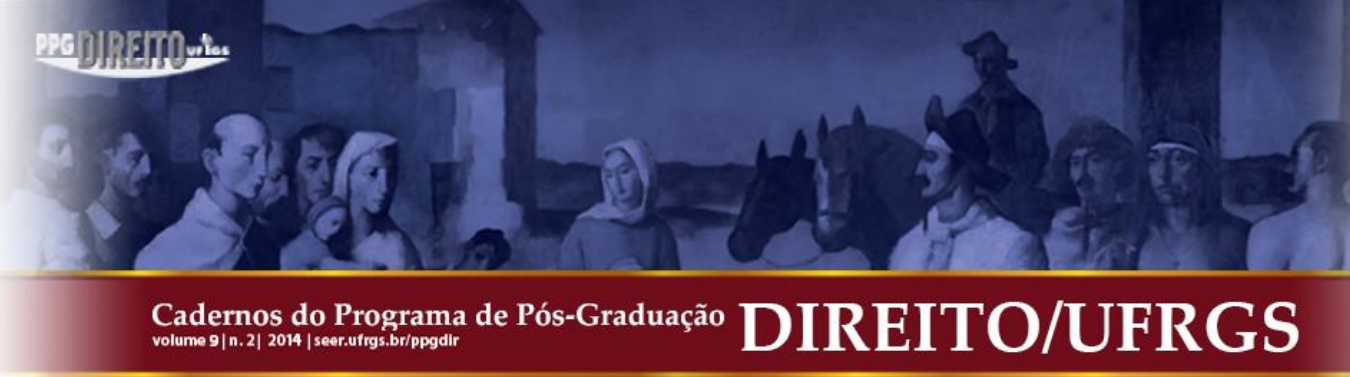

Historicamente, fato é que a centralização do poder ficou restrita ao poder burocrático do Estado, entretanto, nos dias atuais o Estado tem sido ineficiente para alcançar os resultados democráticos e humanitários prometidos à sociedade civil. A morosidade do Poder Judiciário para julgar processos, por exemplo, gera um custo altíssimo para o homem racional, pois ele se vê pressionado pelas circunstâncias tecnológicas, econômicas e sociais a mudar conforme o ritmo do mundo globalizado e no caso brasileiro, é ameaçado pelos juros astronômicos a resolver o mais breve possível os conflitos envolvendo débitos e créditos.

Neste contexto histórico, o homem racional invoca ao Estado Democrático de Direito novas tecnologias contratuais que sejam mais eficientes para chancelar ou consolidar os negócios jurídicos particulares com mais liberdade, igualdade, fraternidade, responsabilidade e democracia.

Como resposta, o Estado tem dividido uma fração do seu poder soberano tradicional e instituiu, por exemplo, a tecnologia da arbitragem com natureza democrática dotada de especificidades para a resolução célere do litígio contratual na área dos direitos patrimoniais disponíveis.

Segundo a Lei da arbitragem brasileira podem ser criadas câmaras de arbitragem especializadas para atuar em determinadas áreas do direito econômico (comercial, trabalhista, intelectual, civil, escolar, etc.), visando complementar o trabalho da Justiça comum. Conforme declara a Lei 9.307 de 1996, a arbitragem é uma tecnologia jurídica colocada à disposição do homem racional e pode ser teoricamente posicionada entre o Leviatã e a anarquia moral, segundo analisou Montarroyos (2010) com o auxílio do programa de pesquisa do autor James Buchanan.

Os custos materiais envolvidos nessa tecnologia correspondem aos gastos monetários com os emolumentos dos árbitros, honorários de peritos, taxas da câmara de arbitragem, etc. Vale lembrar, no entanto, que no Poder Judiciário, eventualmente quando não há o benefício da justiça gratuita, todos os custos do processo são assumidos pelas partes (normalmente a vencida) de modo que nesse aspecto a lógica da justiça arbitral e da justiça comum se assemelham.

Já com relação aos benefícios institucionais, a arbitragem se destaca largamente no quesito celeridade e privacidade ou sigilo do procedimento que é uma cláusula pétrea. De acordo com o artigo 23 dessa Lei toda causa a ela submetida deverá ser resolvida em até seis meses. Depois disso, busca-se um consenso para alargar um pouco mais o prazo ou encerra-se 


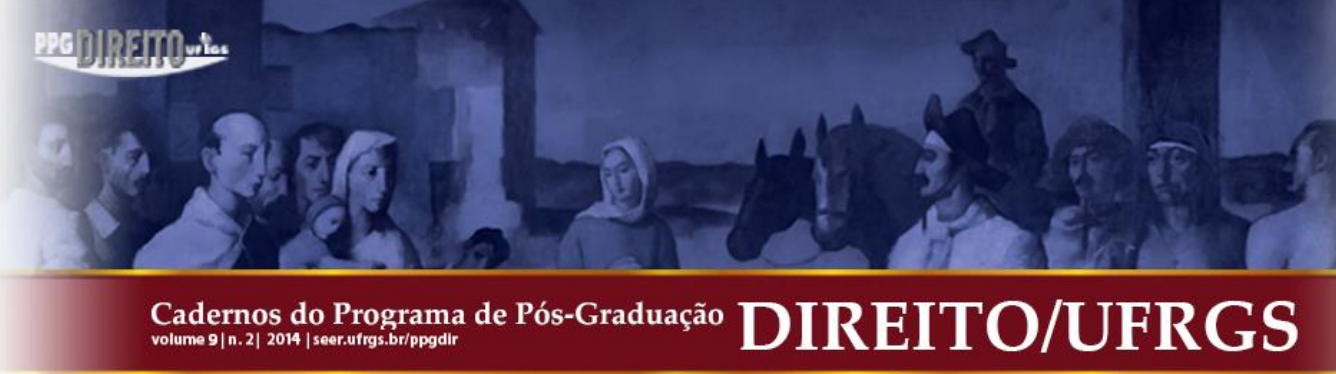

legalmente o procedimento. Além disso, a cláusula pétrea da confidencialidade dos procedimentos arbitrais é um importante atrativo para o empresário racional, principalmente para as empresas que não querem ver os detalhes de suas operações devassados pela publicidade de um processo judicial comum (ALVIM, 2002).

Importante ressaltar que a arbitragem garante maior liberdade e multivocalidade às partes, que assim poderão escolher os árbitros; as regras de julgamento (se de direito ou equidade); bem como a forma de produção das provas. Enfim os clientes da arbitragem poderão compor uma escala de transitividade própria, conjuntamente, e assim realizam os seus trade offs pacificamente, até atingirem o ponto de equilíbrio da balança, ou seja, a justiça de natureza privado-pública.

Como as demais tecnologias civis, a arbitragem possui também regras, princípios e critérios que definem a sua dinâmica contratual. As regras informam como o procedimento irá se desenrolar do começo ao fim, tratando da formalização do compromisso arbitral; do prazo de seis meses para que toda a questão seja resolvida; das obrigações e competências dos árbitros na condução do procedimento; da irrecorribilidade da sentença; da espontaneidade da execução, dentre outras prerrogativas.

Os princípios da arbitragem informam, por sua vez, os valores a serem observados e defendidos pelas partes, pelo árbitro e pelos demais participantes do procedimento, destacando-se os princípios da racionalidade, eficiência, honestidade, boa-fé e dignidade da pessoa humana.

Já os critérios definirão, por sua vez, como a questão deverá ser analisada ou julgada pelo árbitro: se com a utilização de regras de equidade ou de direito. Pelas primeiras, o julgador apreciará a causa desenvolvendo o seu prudente arbítrio, pautado no sentimento subjetivo da equidade do juiz arbitral. Na segunda categoria, a sentença arbitral reproduzirá tecnicamente as regras convencionais do Direito.

Consideramos basicamente que a arbitragem é uma tecnologia da centralização na medida em que deposita na figura do árbitro o poder de julgar a causa, embora seja um centralismo democrático. Ressalte-se, apesar de tudo, que qualquer critério estabelecido será sempre fruto do comum acordo entre as partes: 


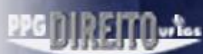

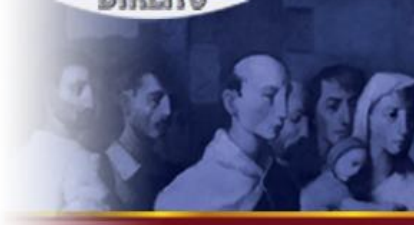 \\ Cadernos do Programa de Pós-Graduação

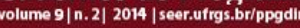

$\S 1^{\circ}$ Poderão as partes escolher, livremente, as regras de direito que serão aplicadas na arbitragem, desde que não haja violação aos bons costumes e à ordem pública.

$\S 2^{\circ}$ Poderão, também, as partes convencionar que a arbitragem se realize com base nos princípios gerais de direito, nos usos e costumes e nas regras internacionais de comércio.

\section{TECNOLOGIA DA DESCENTRALIZAÇÃO CIVIL}

A descentralização civil é mais outra tecnologia pública disponível ao cidadão racional para otimizar os seus interesses no mundo capitalista, democrático e pluralista, e se fundamenta no princípio utilitarista-maximizador.

Usando essa tecnologia civil, o homem racional vai optar por transferir algumas de suas atribuições para uma pessoa física ou jurídica, especializada em determinada tarefa, por exemplo, administração de condomínios, com a expectativa de aumentar a eficiência dos serviços coletivos, configurando-se, portanto, a terceirização.

Mais uma vez, pode-se falar em regras, princípios e critérios durante a utilização dessa tecnologia, além dos custos, riscos e benefícios inerentes. As regras delimitam a forma de atuação da administradora terceirizada; o que compete a ela fazer; e o que permanece sob a responsabilidade do terceirizante.

No caso do condomínio edilício, em que é obrigatória a figura do síndico, essa figura pode terceirizar algumas de suas funções, a exemplo do que dispõe o Código Civil:

Art. 1.348. Compete ao síndico:

V - diligenciar a conservação e a guarda das partes comuns e zelar pela prestação dos serviços que interessem aos possuidores;

VI - elaborar o orçamento da receita e da despesa relativa a cada ano;

$\S 2^{\circ} \mathrm{O}$ síndico pode transferir a outrem, total ou parcialmente, os poderes de representação ou as funções administrativas, mediante aprovação da assembleia, salvo disposição em contrário da convenção.

Tendo em vista que o objetivo de um condomínio é a produção do bem-estar social do grupo, a descentralização deve estar pautada necessariamente nos princípios da 


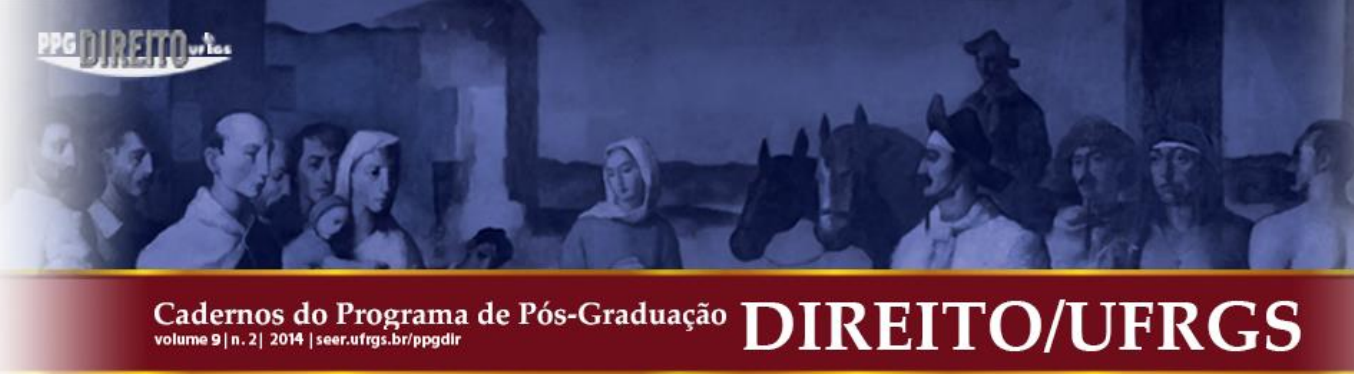

responsabilidade coletiva e probidade. Entretanto, o principal critério utilizado para se avaliar a pertinência ou não da terceirização, bem como a atuação do síndico, será utilitaristamaximizador, ou seja, fundamentado na identificação da eficiência dos processos por meio do qual se buscará o melhor desempenho político, social e econômico. A eficiência é tão necessária nesse tipo organização que os condôminos, segundo o que dispõe o Código Civil, poderão destituir o síndico caso ele não administre convenientemente o condomínio:

Art. 1.349. A assembleia, especialmente convocada para o fim estabelecido no $\S 2$ do artigo antecedente, poderá, pelo voto da maioria absoluta de seus membros, destituir o síndico que praticar irregularidades, não prestar contas, ou não administrar convenientemente o condomínio.

A descentralização garante a ordem patrimonial do condomínio e traz uma rápida metodologia de solução de problemas cotidianos, pois as administradoras especializadas contam com assessoria jurídica e contábil permanente e dispõem, também, de uma rede eficaz de outros prestadores de serviços.

Os custos materiais dessa tecnologia envolvem gastos com os honorários da administradora e todas as despesas que decorrem da realização de benesses para o condomínio. Além disso, existe o custo de oportunidade internalizado pelo síndico, pois eventualmente será necessário tomar alguma decisão política contra um de seus vizinhos, como autorizar a abertura de um processo judicial de cobrança de taxas condominiais atrasadas, o que, de certo modo, tem o poder de acirrar a animosidade pelos corredores do prédio.

O custo de oportunidade ou psicológico pode ser nesse caso a abdicação da amizade, simpatia e dos procedimentos éticos em favor do processo civil ou procedimento arbitral envolvendo os vizinhos. Também, a descentralização civil traz o risco do esvaziamento da vida política do condomínio, pois a concentração das decisões nas mãos da administradora conspira contra o sentimento de pertença da comunidade, com os condôminos deixando de perceber o todo como parte integrante de seu patrimônio pessoal-coletivo, passando infelizmente a encará-lo como se fosse uma colônia ou província governada por uma distante metrópole, a matriz administradora. 


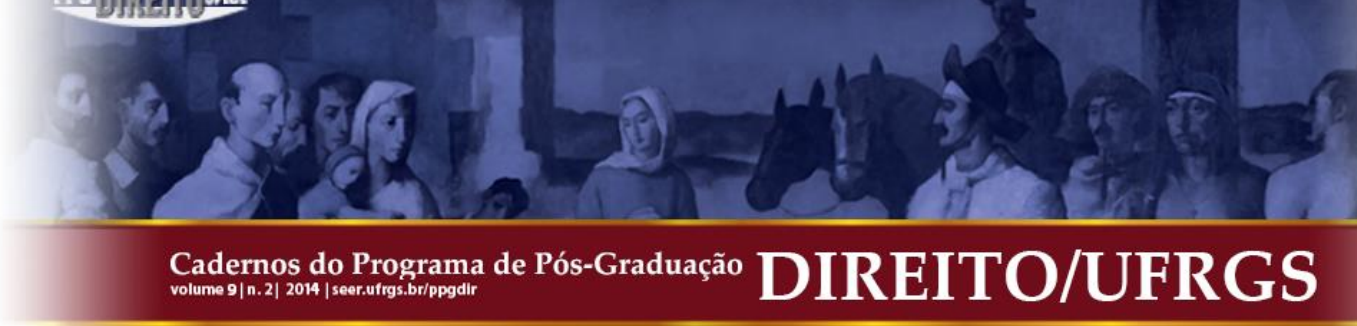

\section{TECNOLOGIA DA COALIZÃO}

O cidadão racional percebe que formar uma comunidade com pessoas que almejam objetivos em comum constitui um meio eficiente para aumentar benefícios e reduzir custos institucionais. Para tanto, há diversas tecnologias da coalizão previstas em Lei à disposição do cidadão e todas pressupõem a celebração de um contrato social, contendo regras, critérios e princípios para orientar a utilização do seu sistema operacional. Existem associações, empresas, união matrimonial, e condomínios como exemplos desse tipo de tecnologia. No caso específico do condomínio, a escala de transitividade do indivíduo racional contém basicamente duas possibilidades de escolha: ou ele fica sozinho em uma casa isolada, e aí consome plenamente o seu direito de propriedade privada, livre de custos sociais expressivos; ou então, resolve integrar um condomínio, assumindo benefícios de um ambiente possivelmente mais seguro, melhor equipado e com mais conforto, pagando o custo subjetivo de ter a sua liberdade individual tolhida ou reduzida em detrimento do bem comum, que nesse caso é um bem coletivo instrumental.

O trade off por essa ou aquela opção vai depender do cálculo racional contextualizado, entretanto, é importante ressaltar que a operação economicista em torno dos custos monetários não é mais determinante para se prever a escolha final do homem racional, pois está em jogo também o prazer de se viver no condomínio; e esse prazer pode ultrapassar o valor das mensalidades. Ou seja, elementos humanos como liberdade, status social, bem-estar e sensação de segurança afetarão incisivamente a decisão do homem racional!

As regras para a criação, funcionamento e extinção de um condomínio estão em linhas gerais definidas pelo Código Civil. Acerca da criação de um condomínio edilício, deverá acontecer, por exemplo, uma convenção entre os condôminos para se definir ou repactuar-se as normas específicas que regulam obrigatoriamente as condutas e os procedimentos nessa comunidade. O Código Civil confere obrigatoriedade à convenção nos seguintes termos:

Art. 1.333. A convenção que constitui o condomínio edilício deve ser subscrita pelos titulares de, no mínimo, dois terços das frações ideais e torna-se, desde logo, obrigatória para os titulares de direito sobre as unidades, ou para quantos sobre elas tenham posse ou detenção.

Parágrafo único. Para ser oponível contra terceiros, a convenção do condomínio deverá ser registrada no Cartório de Registro de Imóveis. 


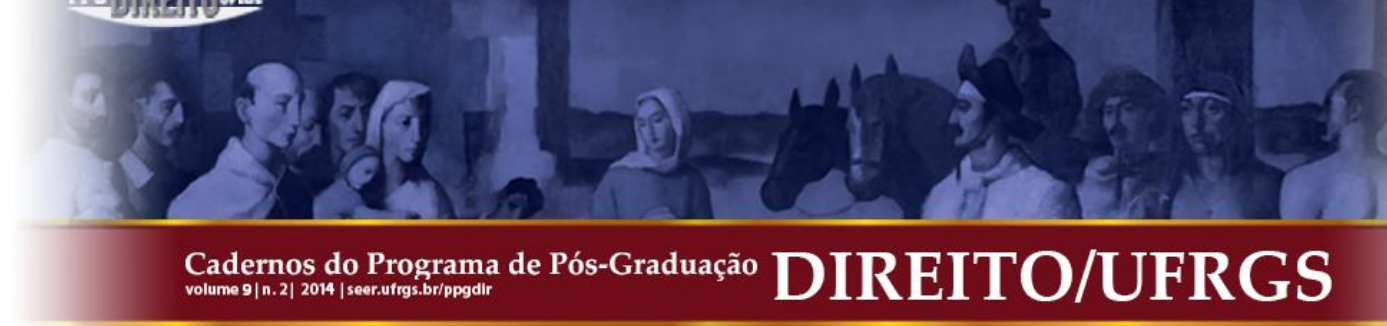

Art. 1.334. Além das cláusulas referidas no art. 1.332 e das que os interessados houverem por bem estipular, a convenção determinará:

I - a quota proporcional e o modo de pagamento das contribuições dos condôminos para atender às despesas ordinárias e extraordinárias do condomínio;

II - sua forma de administração;

III - a competência das assembleias, forma de sua convocação e quorum exigido para as deliberações;

IV - as sanções a que estão sujeitos os condôminos, ou possuidores;

$\mathrm{V}$ - o regimento interno.

No condomínio, o homem racional pode ajustar essa tecnologia jurídica de forma que atenda melhor às suas preferências. Talvez seja essa a maior vantagem desse tipo de tecnologia jurídica, pois tudo que o homem racional deseja é ser livre dentro da Lei. Concretamente, a convenção do condomínio oferece critérios, ou seja, estruturas praticantes a respeito de autorização ao síndico para terceirizar ou não a administração; a respeito da melhor data para se pagar a mensalidade condominial; a respeito do quórum de deliberação das assembleias, dentre outras situações cotidianas.

Os princípios que fazem parte do sistema operacional dessa tecnologia serão aqueles que norteiam os grupos de um modo geral, tais como o princípio da solidariedade, da probidade, da humanidade, do respeito mútuo, etc.

No condomínio encontramos especialmente o problema do free rider ou "carona". Sendo o próprio condomínio residencial um bem coletivo puro, ou seja, não excludente e indivisível onde seus bens, serviços e equipamentos são de direito pertencentes a todos os condôminos proprietários e residentes, não há como expulsar ou promover constrangimentos no uso da piscina, do salão de festas, dos corredores, da água, do estacionamento, da portaria, etc., que pertencem a todos, sem distinção. Por isso, legalmente, o mal pagador e o inadimplente serão tratados em pé de igualdade com o bom pagador.

Entretanto, o maior problema não é a igualdade de tratamento obrigatório no edifício, mas a falta de dinheiro para pagar os empregados, manter a limpeza e a segurança do prédio, prover benfeitorias necessárias e atender às novas demandas da comunidade. É nesse momento crucial da economia, portanto, que o líder, ou seja, o síndico se vê diante de uma 


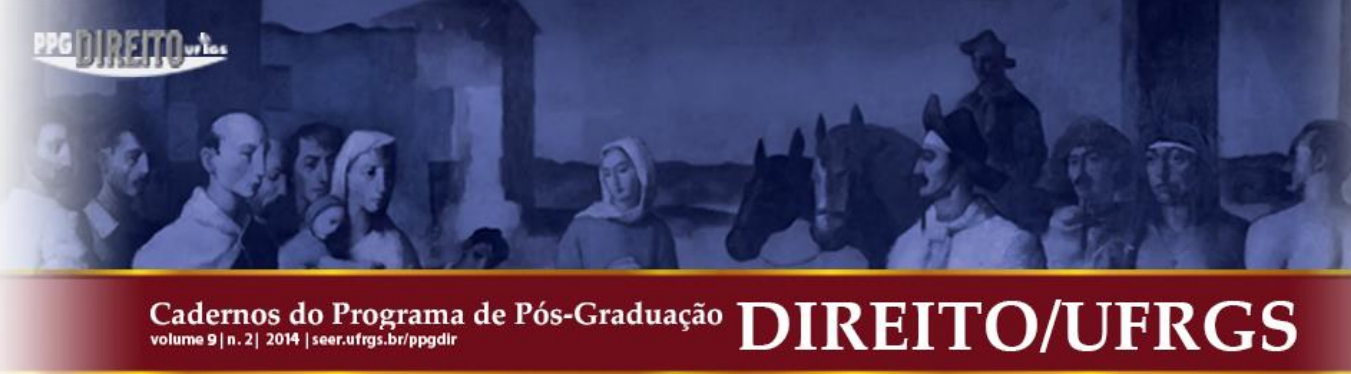

crise de legitimidade. Afinal, o que se coloca em xeque nesse caso é até onde vai o seu poder político e até onde vai a regra de eficiência do mercado.

Surge, aqui, um dilema institucional entre ser democrático e ser autoritário. Ser flexível nos prazos de pagamento mensal ou radicalizar o sistema de cobrança.

O agravante nisso tudo é que o free rider que é um membro oportunista avalia que o pagamento em datas irregulares ou o atraso de vários meses não afetam o livre uso dos espaços no condomínio. Mas por outro lado, infelizmente, esse fato prejudica a sua comunidade, criando males públicos diversos dentre eles a desordem administrativofinanceira. Como solução, se o líder for racional vai se comportar como empreendedor e distribuirá uma série de incentivos paralelos de atração e de convencimento dos condôminos que perderam de vista a sua responsabilidade e a sua importância social no prédio.

Deixando de lado o autoritarismo, promovendo calúnias, assédios morais, ou retaliações diversas, o síndico poderá preferir alternativas democráticas e modernas como, por exemplo, perdoando os devedores, reduzindo o impacto das multas nos meses atrasados, ou ainda promovendo jantares e festas dentro e fora do prédio a fim de angariar recursos extras para garantir a boa administração do condomínio.

Nesse processo de escolha das estratégias, existe, no entanto, o risco de o síndico ficar impopular junto à maioria dos bons pagadores que podem cobrar dele a implantação de um modelo mais repressivo de correção das dívidas, que tecnicamente é um mal público nesse contexto.

Antevendo essa possibilidade de não agradar "gregos nem troianos" o síndico racional poderá preferir não expor sua reputação às críticas e contrata por isso uma administradora de condomínios, terceirizando serviços, evitando desgastar a sua imagem pessoal e administrativa; adotando, portanto, um modelo impessoal e tecnicista de gerenciamento do bem comum. Como resultado institucional, o condomínio deixa de ser uma comunidade moral ou política, e se transforma numa máquina de calcular custos e benefícios monetários, um "autômato".

\section{DISCUSSÃO}

Para o cidadão racional a informação é um meio que deve otimizar o seu desempenho econômico na realidade. Estrategicamente, ele calcula custos e providencia meios adequados 


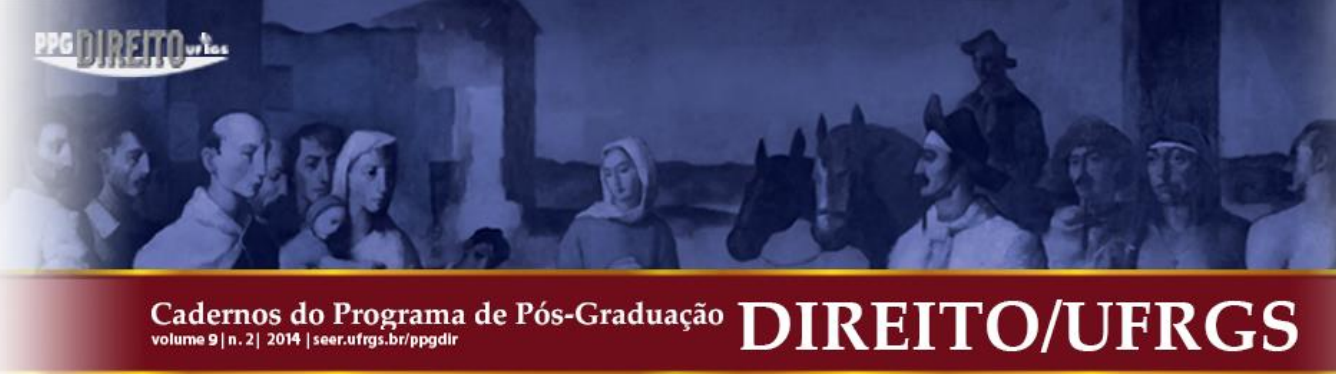

para concretizar seus projetos com menos riscos e prejuízos; porém, às vezes, recorre a pessoas especializadas, visando otimizar a utilização das complexas tecnologias informacionais do Código Civil.

Considerando a ideia de que a lei é usada para reduzir incertezas, o professor Heraldo Montarroyos (2010) argumentou que o contexto público dos contratos é inicialmente caracterizado pela incerteza social. Completando essa afirmação, Anthony Downs (1999) considerou em sua "Teoria econômica da democracia" que os indivíduos e o pesquisador raramente possuem dados completos para eliminar toda a incerteza do ambiente. Entretanto, no contexto da incerteza, os interesses, as preferências e as convicções individuais não constituem necessariamente um obstáculo definitivo para os interesses contratuais, tendo em vista que existem regras, princípios, critérios e instituições disponíveis por Lei que restringem a ameaça da anarquia ilícita ou hobbesiana e instrumentalizam os interesses das partes que pretendem celebrar os acordos democráticos.

Apesar de serem a generalidade e a publicidade requisitos fundamentais de qualquer Lei, o homem racional percebe que deve procurar ajuda de um especialista jurídico. Ou seja, o usuário das tecnologias civis até pode ler o "manual" público que é o Código Civil, mas não entende plenamente a sua linguagem jurídica operacional, daí surge a necessidade de um advogado, de um juiz arbitral, de um defensor público etc.

Curiosamente, Hobbes (2002) também justificou a existência do Estado a partir da necessidade das tecnologias ou máquinas jurídicas. No estado de natureza, segundo ele, não existiriam tecnologias civis da ordem pública, justificando, portanto, a construção coletiva pactuada do estado civil para se produzir informações civis necessárias que ajudariam as pessoas a não caírem novamente no estado de violência de todos contra todos.

É importante ressaltar que a postura do indivíduo e do Estado diante da Lei mudou ao longo dos tempos, e o homem racional especificamente busca uma tecnologia jurídica mais leve, democrática, inteligente e com a possibilidade oficial de graduar as regras. Além disso, considerando os limites da Lei como sendo a ordem pública e os bons costumes, a racionalidade do indivíduo pretende atuar nesse intervalo selecionando e graduando as tecnologias que melhor otimizariam as estratégias, invocando-se politicamente os princípios da autonomia e da responsabilidade dos contratantes. Nesse quadro teórico, conforme sugeriu Buchanan (1975), o Leviatã domesticado pela Constituição Democrática deveria proporcionar ao homem racional um variado e completo cardápio de regras, critérios e princípios para que 


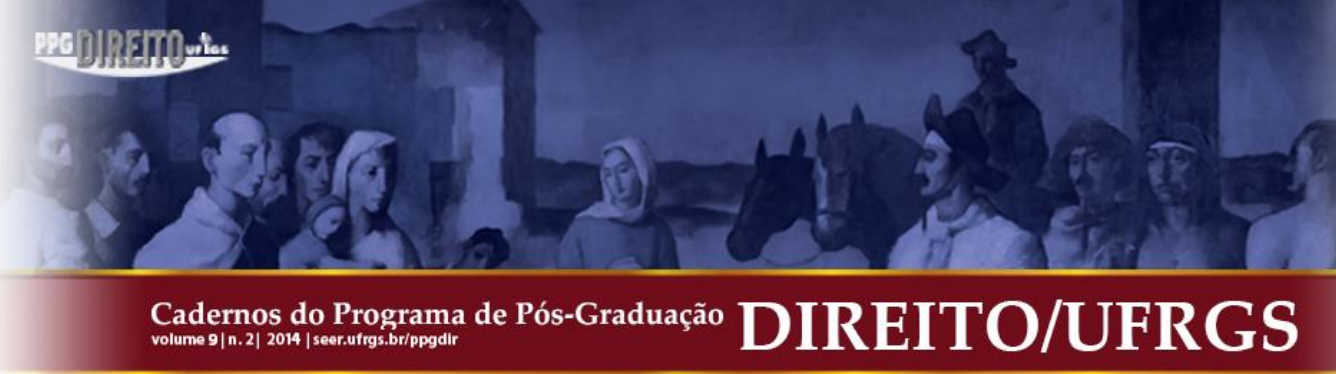

ele possa direcionar seus negócios livremente dentro da Lei, induzindo consequentemente a racionalidade privada dos indivíduos e das empresas a produzirem civilizadamente o bem público de maneira eficiente e equilibrada.

Evitando regressar ao estado quase caótico da ilegalidade, o cidadão racional procura saber quais são o caminho e os procedimentos corretos que devem ser adotados nos contratos civis. Por isso, ele busca informações, especificamente aquelas disponibilizadas pelas tecnologias jurídicas que são mais confiáveis do ponto de vista público.

$\mathrm{O}$ estado de natureza hobbessiano é o reino das ilicitudes e ilegalidades. Nessa direção, prescreve o artigo 186 do Código Civil que: “Aquele que, por ação ou omissão voluntária, negligência ou imprudência, violar direito e causar dano a outrem, ainda que exclusivamente moral, comete ato ilícito". Consequentemente, em decorrência dos atos ilícitos praticados a pessoa poderá sofrer diversas penalidades: pagar multas e indenizações; anular seus contratos; ou até em casos extremos incorrer na pena de prisão.

No estado de natureza hobbesiano como já definiu Buchanan (1975), o indivíduo leva uma vida "pobre, curta e miserável". Entretanto, conforme destacou Montarroyos (2009), o estado de natureza não é consequência apenas da maldade humana como faz crer uma leitura superficial da teoria de Hobbes (2002). De fato, o homem racional deseja a glória, a fama, o poder e o dinheiro e tende a privatizar tudo que lhe agrada usando meios abusivos que atentam contra a dignidade da pessoa humana por meio daquilo que se convencionou chamar de individualismo possesivo. Mas a falta de informações públicas é um grande mal nessa sociedade hipotética, o estado de natureza, provocando nos indivíduos a incapacidade de fazer qualquer previsão técnica relativa ao funcionamento dos acordos celebrados, visto que não existe um padrão ou régua oficial para medir a extensão dos direitos e deveres de cada um e que seja ao mesmo tempo acompanhado da possibilidade do castigo da parte do Leviatã quando um dos contratantes violar o padrão de conduta oficial esperado pela sociedade moderna.

Diante dessa falta, o medo contamina as pessoas, ou como já definiu Montesquieu, o estado de natureza desenvolve uma situação precária e sem futuro promissor fazendo com que as pessoas tenham receio permanente de tomar atitudes empreendedoras, temendo invadir ou provocar os ânimos dos outros indivíduos na comunidade, consequentemente subsiste uma sociedade tímida e acanhada. Segundo Montesquieu (2004, livro I, cap. 2): 
Hobbes pergunta: "por que, se não se encontram naturalmente em estado de guerra, os homens andam sempre armados? E por que têm chaves para fechar suas casas?" Mas não percebe que está atribuindo aos homens, antes do, estabelecimento das sociedades, aquilo que só pode acontecer após este estabelecimento, que fará com que encontrem motivos para atacarem-se e defenderem-se. Ao sentimento de sua fraqueza, o homem acrescentaria o sentimento de suas necessidades.

Assim, outra lei natural seria aquela que lhe inspiraria a procura da alimentação. Eu disse que o temor levaria os homens a fugirem uns dos outros: mas os sinais de um temor recíproco encorajariam-nos a só aproximarem. Aliás, eles seriam levados a isto pelo prazer que um animal experimenta ao sentir a aproximação de outro animal de sua espécie. Além disso, o encanto que os dois sexos inspiram um ao outro devido a sua diferença aumentaria este prazer; e apelo natural que sempre fazem um ao outro seria uma terceira lei.

Além do sentimento que os homens têm em primeiro lugar, ainda conseguem possuir conhecimentos; assim, possuem um novo motivo para se unirem; e o desejo de viver em sociedade é uma quarta lei natural.

É no modelo hipotético de Thomas Hobbes (2002) conforme analisou James Buchanan (1975), que tomamos conhecimento das condições institucionais que favorecem a produção dos bens privados com absoluta liberdade e relativa eficiência até o momento crucial em que começam a surgir objetivamente males públicos diversos, como desordem, violência, insegurança, imprevisibilidade, poluição, etc., prejudicando assim a eficiência das trocas e a própria ordem patrimonial egoísta, baseado na permissividade do cotidiano.

A solução contratualista é fundamental para Hobbes (2002). Apesar de os indivíduos trocarem o estado de natureza pelo estado civil sem nunca terem conhecido as propriedades naturais da segunda alternativa, a expectativa racional extrapola nesse contexto o conhecimento real das coisas e desse modo os indivíduos superam o dilema trocando o certo pelo duvidoso.

Com a ajuda do Leviatã, os acordos passam a ter um formato ou desenho institucional preocupado em manter a ordem pública e, ao mesmo tempo, os interesses privados. O desenho dos contratos se torna objetivista e regralógico, ou seja, procura escapar do risco da subjetividade que é a porta de entrada na direção do estado de natureza e, por conseguinte, as regras do Direito positivo são graduadas ao nível máximo de formalismo tentando garantir a segurança jurídica. 


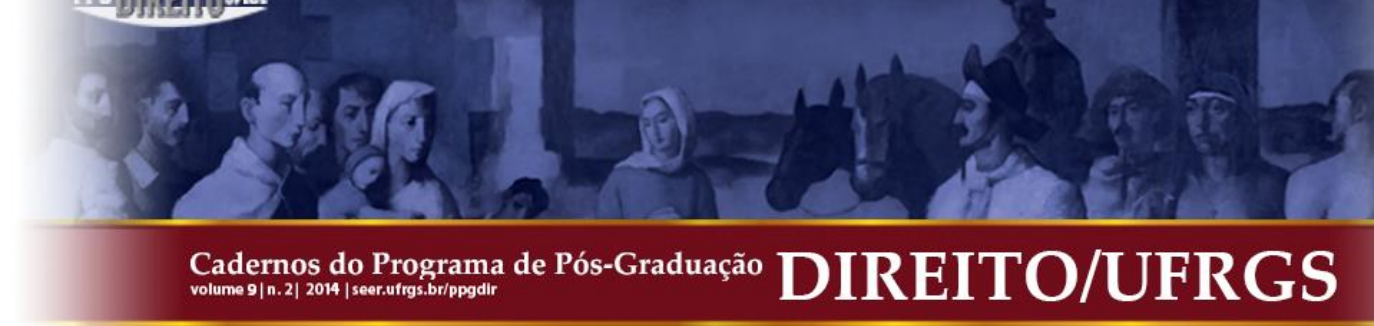

\section{CONSIDERAÇÕES FINAIS}

Na visão instrumental da racionalidade econômica, o contrato civil é uma tecnologia da informação dotada de um sistema operacional de regras, princípios e critérios que informam os direitos e deveres, custos e benefícios contratuais; ao mesmo tempo, o contrato disponibiliza um processo institucional capaz de reconciliar os interesses, preferências e convicções individuais com a racionalidade social, embora nem sempre haja um equilíbrio perfeito entre essas duas racionalidades, na prática e na teoria, por envolver uma sociedade democrática e capitalista repleta de incertezas e instabilidades.

Com a informação pública proporcionada pela tecnologia da negociação, centralização, descentralização e da coalizão, tecnicamente o agente racional encontra meios institucionais para escapar da ilegalidade e otimizar a sua participação na ordem jurídica. Os custos informados por essas tecnologias contratuais podem ser materiais ou subjetivos. Nessa última categoria, os custos de oportunidade foram representados nesse estudo pelo sacrifício da liberdade e pela supressão do poder unilateral de julgamento do homem racional, observados automaticamente no processo de troca ou substituição da anarquia hobbesiana pelo estado civil.

Chamamos a atenção também em nosso modelo que existem usuários racionais manipulando os comandos institucionais em maior ou menor intensidade, formando consequentemente uma escala gradativa de utilidade no cotidiano, onde certas regras, princípios e critérios poderão ser super-utilizados; utilizados; subutilizados; inutilizados intencionalmente; ou ignorados por completo quando faltam informações de ordem pública.

As tecnologias contratuais ou civis são bens públicos gratuitos e estão disponíveis para qualquer cidadão usá-las livremente, entretanto, o desempenho dessas tecnologias varia empiricamente na sociedade porque existem incentivos negativos e positivos atuando nas relações interindividuais, pressionando o homem racional a rever frequentemente as suas estratégias. Entre os incentivos negativos, que afastam o consumo das tecnologias jurídicas ou prejudicam a sua qualidade ou validez, inclui-se a renda limitada; a escassez de recursos; a falta de informação e educação; a desordem política; e o burocratismo. Entre os incentivos positivos, que atraem o consumo das tecnologias civis, encontra-se a expectativa dos 


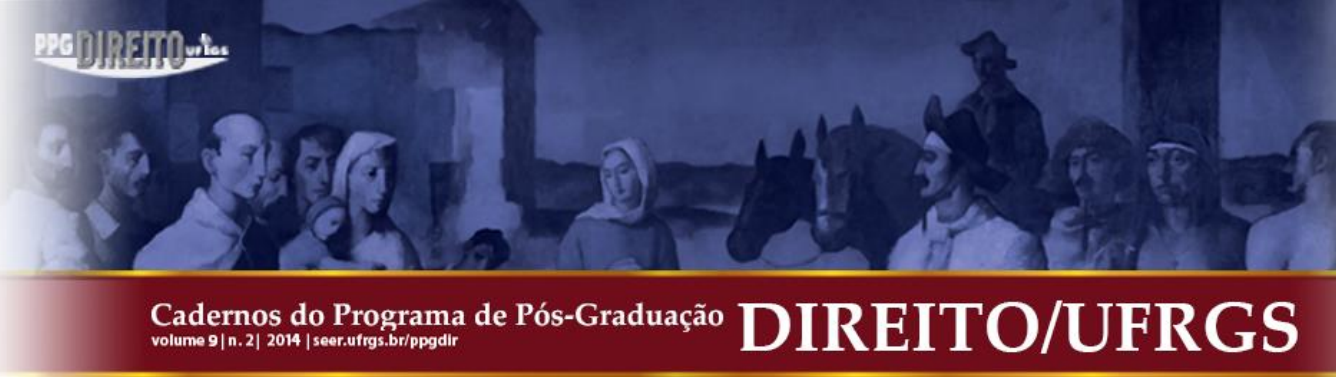

benefícios institucionais como ordem, segurança, garantias individuais, previsibilidade dos acontecimentos contratuais, fiscalização pública, dentre outras vantagens contratuais.

Conclusivamente, podemos afirmar que existe uma economia política contratual no Código Civil que é informada particularmente por cada uma de suas tecnologias jurídicas. Ficou patente na descrição da dinâmica institucional dessas tecnologias civis apresentada nas seções anteriores que existem custos, benefícios e riscos institucionais em um contexto de incertezas e instabilidades.

Os custos podem ser materiais ou subjetivos. Nessa última modalidade, há pelo menos dois tipos imediatos: redução do poder de julgamento unilateral e supressão da autonomia individualista.

Os custos subjetivos estão na base de qualquer contrato onde se pressupõe a troca da anarquia (moral ou imoral, lícita ou ilícita, hobessiana ou lockiana) em favor do estado civil da legalidade. Consequentemente, acredita-se que essa troca será produtiva desde que haja informações técnicas que aumentem a segurança jurídica e nos afastem do estado de natureza hobbesiano.

Os benefícios compensam os custos, caso contrário, seria irracional internalizá-los propositalmente. Incluem bens como ordem, segurança, previsibilidade, garantias individuais e informações de como se evitar a ilegalidade e ilicitude.

Porém, a situação mais vibrante da economia política civil coloca-se virtualmente diante do consumidor com a possibilidade de duas alternativas extremas: o estado de natureza versus o estado civil.

Na primeira opção, encontram-se tecnologias sociais baseadas na força, malandragem, esperteza, medo, vandalismo, etc., que são capazes de produzir com o máximo de eficiência bens privados, uma vez que não existem restrições públicas nem éticas entre os indivíduos. Dentro desse sistema faltam, no entanto, garantias básicas ao direito à vida, à segurança e à propriedade, que são custos de oportunidades que poderiam ser eliminados desenvolvendo-se outro sistema de trocas com a proteção, monitoramento e informação de um Poder Público universal. Portanto, ao encontrar esta segunda alternativa na prateleira constitucional o indivíduo pode refazer os seus cálculos e avaliar finalmente que será lucrativo assumir certos custos ou sacrifícios institucionais com a expectativa de produzir meios eficientes para otimizar ao máximo as suas negociações. Desse modo, são internalizados custos subjetivos e financeiros (por exemplo, pagando serviços burocráticos e a papelada do cartório) no sentido 


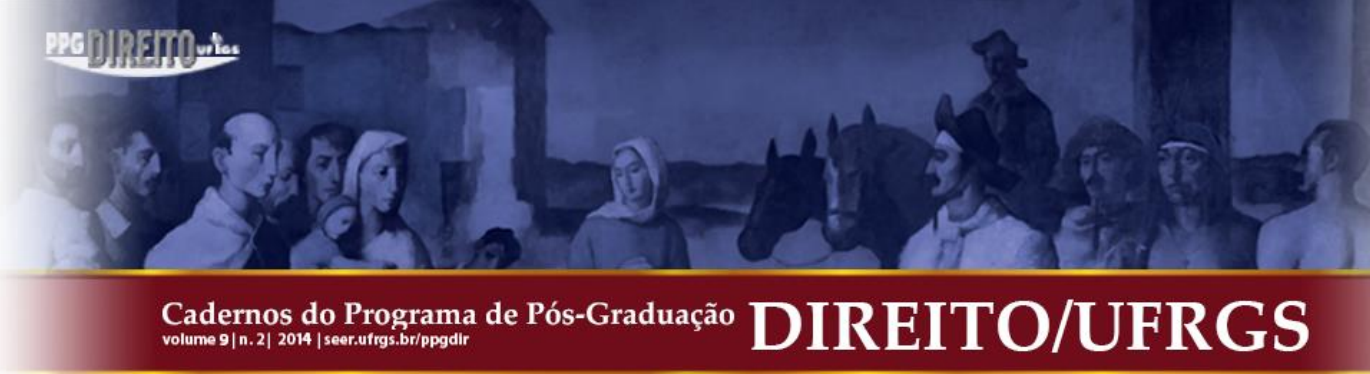

de evitar o estado de natureza hobbesiano que é um péssimo instrumento para se compatibilizar a racionalidade justa, democrática e humana com o princípio da eficiência.

\section{REFERÊNCIAS}

ALVIM, J. E. Carreira. Comentários à lei de arbitragem. Rio de Janeiro: Lumen Juris, 2002.

BRASIL. Lei 9.307, de 23 de setembro de 1996. Dispõe sobre a arbitragem. Disponível em: <http://www.planalto.gov.br/ccivil_03/leis/19307.htm>. Acesso em: 11 jul. 2014.

Lei 10.406, de 10 de janeiro de 2002. Código Civil Brasileiro. Disponível em: <http://www.planalto.gov.br/ccivil_03/leis/2002/110406.htm>. Acesso em: 11 jul. 2014.

BUCHANAN, James. The limits of liberty: between anarchy and Leviathan. Chicago: The University of Chicago Press, 1975.

1993.

Custo e escolha: uma indagação em teoria econômica. São Paulo: Inconfidentes,

DOWNS, Anthony. Teoria econômica da democracia. São Paulo: Edusp, 1999.

HOBBES, Thomas. Leviatã: ou matéria, forma e poder de um estado eclesiástico e civil. São Paulo: Martin Claret, 2002.

MIRANDA, Maria Bernadete. Teoria geral dos contratos. Direito Brasil. vol. 2, n. 2, 2008. Disponível em: <http://www.direitobrasil.adv.br/artigos/cont.pdf〉. Acesso em: 22 jun. 2014.

MONTARROYOS, Heraldo Elias. A economia política constitucional do prêmio Nobel James Buchanan. Economia Ensaios, n. 23, v. 2, 2009. Disponível em: <http://www.seer.ufu.br/index.php/revistaeconomiaensaios/article/view/3741>. Acesso em: 10 jul. 2014.

Inventário epistemológico das ideias neocontratualistas do economista James

Buchanan: a racionalidade econômica e sua aplicabilidade microssocial. Direito $e$ 
